\title{
EDUCATION NEEDS OF NURSES AND HEALTHCARE ASSISTANTS PROVIDING LEVEL II PALLIATIVE CARE
}

Sharon Agbana ${ }^{1,2}$, Lynn White ${ }^{3}$, Michael Connolly ${ }^{1,2}$, Suzanne Guerin ${ }^{3}$ \& Phil Larkin ${ }^{1,2}$

1: UCD School of Nursing, Midwifery \& Health Systems, University College Dublin

2: Our Lady's Hospice and Care Services, Harold's Cross, Dublin

3: UCD School of Psychology,

Poster presented at the $16^{\text {th }}$ World Congress of the European Association for Palliative Care. P02 - 431

\section{INTRODUCTION:}

Palliative care is an approach of care that aims to improving quality for patients with life limiting conditions and their families through the prevention and relief of suffering, through early identification, assessment, and treatment of pain and other distressing symptoms: could be physical, psychological and spiritual(i). Palliative care is delivered at three levels; Levels 1 (General Palliative care), Level 2 (Supportive Palliative care) and Level 3 (Specialist Palliative Care)(ii)

\section{STUDY AIMS AND OBJECTIVES:}

This study aimed to explore the experiences of nurses and care assistants providing supportive care in level 2 palliative care, focusing on their educational needs. The objectives of the study were:

- To explore the experience and understanding of level 2 Palliative care Nurses and Healthcare assistants.

- To identify the specific education needs on nurses and healthcare assistants providing level 2 Palliative care.

\section{METHODOLOGY:}

This study was conducted qualitatively - adopting a phenomenology approach. Purposive sampling was used to identify participants for focus group interviews. Verbatim transcripts of interviews were analysed using van Manen's method for phenomenological analysis(iii), classifying the findings into themes and subthemes, with each theme addressed in relation to existing literatures.

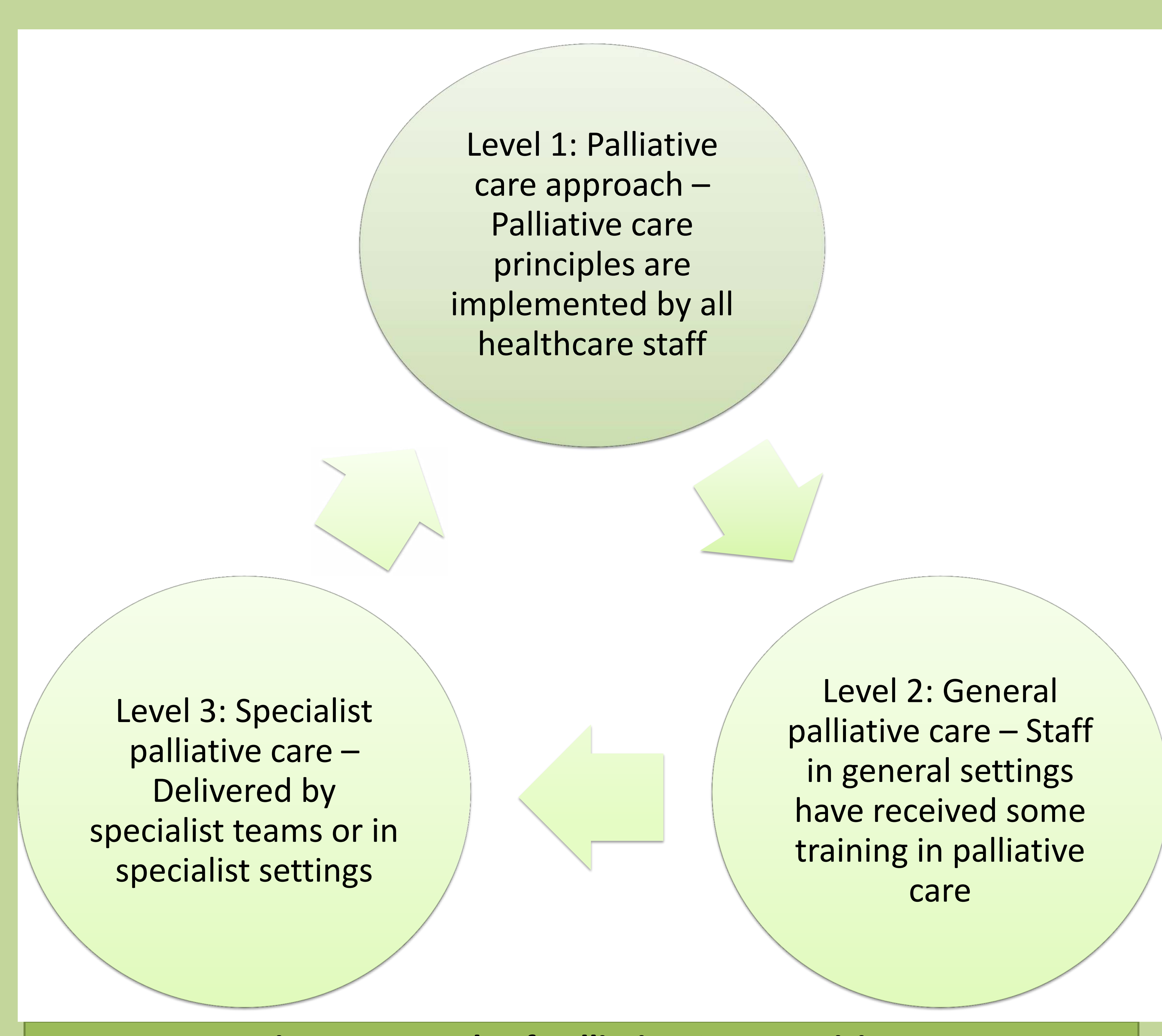

Figure 1: Levels of Palliative Care Provision

\section{RESULTS}

"... they take more of your time ... They need more one to one. They need more medication. They need more emotional support for $m$ all of us in the team." (FG, 1)
" ... for me I think it's more of experience on the ward rather than training." (FG, 1)

“... because we have more palliative care here now and we have been told we'll be moistly palliative therefore we need more training." (FG, 2$)$
"I suppose out of all the symptoms, anxiety and fear could be the most challenging ... because there are so many

facets and everybody experiences differently and everyone has their own way of coping." (FG, 2)

\section{Identified Educational Needs of Nurses and Health Care Assistants in Level 2 Palliative Care}

\begin{tabular}{|c|c|c|c|c|c|c|c|}
\hline $\begin{array}{c}\text { Understanding } \\
\text { delivery of } \\
\text { palliative care at } \\
\text { level } 2\end{array}$ & $\begin{array}{c}\text { Developing } \\
\text { communication } \\
\text { skills }\end{array}$ & $\begin{array}{l}\text { Assessment of } \\
\text { patients for } \\
\text { referral to level } \\
3 \text { palliative care }\end{array}$ & $\begin{array}{l}\text { Awareness and } \\
\text { management of } \\
\text { symptoms in } \\
\text { the patients } \\
\text { with palliative } \\
\text { care needs }\end{array}$ & $\begin{array}{c}\text { Time } \\
\text { Management }\end{array}$ & $\begin{array}{l}\text { Recognition and } \\
\text { management of } \\
\text { complex needs }\end{array}$ & Self-care & $\begin{array}{l}\text { Awareness of } \\
\text { palliative care } \\
\text { education } \\
\text { programmes - } \\
\text { funding }\end{array}$ \\
\hline
\end{tabular}

\section{Conclusions:}

- The findings highlight the educational needs of nurses and health care assistants delivering level 2 palliative care, while demonstrating the importance of continuing education regardless of years of experience

- Addressing education needs ensures that individual healthcare professionals and the organisational needs are met, while delivering effective care to patients.

References: (i) World Health Organisation (2002) "Definition of Palliative Care", WHO Available online at: http://www.int/cancer/palliative/definition/en/; (ii) Department of Health \& Children (2001) Report of the National Advisory Committee on Palliative Care. Dublin, Stationery Office. (iii) Van Manen, M. (2016) Researching lived experience: human science for an action sensitive pedagogy. London: Routledge 